\title{
UTENOS REGIONO SKIRTINGŲ LYČIŲ PAAUGLIŲ MITYBOS İPROČIŲ PALYGINIMAS
}

\author{
Žydra Kuprėnaitė, Jolita Lubienė, Ramunė Ubeikienė \\ Utenos kolegijos Medicinos fakultetas
}

Raktažodžiai: paaugliai, lytis, mitybos ịpročiai, sveika mityba, mokykla.

\begin{abstract}
Santrauka
Pastaruoju metu pastebimas valgymo sutrikimu - anoreksijos, bulimijos, persivalgymo - plitimas. Nerimą kelia šių sutrikimų pasireiškimas paauglysteje. Svarbu palyginti skirtingų lyčių paauglių mitybos ịpročius, siekiant įžvelgti galimas tendencijas bei numatyti galimų sutrikimų prevencijos priemones, kadangi netinkamos mitybos ipročiai, valgymo sutrikimai paaugliams turi daugiau neigiamy pasekmių, nei suaugusiems. Tyrimu siekta palyginti skirtingų lyčiu paauglių mitybos ịpročius. Tyrimas atskleide, kad tam tikrais aspektais išryškèja vienos, o jau kitais - kitos lyties tiriamujų mitybos ipročių taisyklingumas, tačiau ypač svarbu tinkamos mitybos ịpročių formavimu reikiamai rūpintis tiek individuliai - šeimos, kurioje auga paauglys, tiek mokyklos - kasdieninès mokinio aplinkos, tiek visuomeniniu lygmenimis.
\end{abstract}

\section{Ivadas}

$\mathrm{Ne}$ vienerius metus Lietuvoje vykdomi įvairūs projektai visuomenès švietimo sveikatos, sveikos mitybos ir maisto pasirinkimo klausimais (darželinukams ir pradinukams dalinami pieno produktai, vaisiai, daržovès, seminarai vyresniems moksleiviams bei visuomenei), rezultato nedavè. Tai atskleide Vilniaus universiteto Visuomenès sveikatos instituto atliktas Lietuvos gyventojų mitybos ipročių tyrimas. Apklausus 1001 respondentą visoje šalyje, paaiškèjo, kad lietuvių mityba - kaip kad prieš penkerius metus buvo netinkama ir nepalanki sveikatai, taip ir dabar yra panaši, kitaip tariant, - prasta [3]. Pastaruoju metu vyraujant liekno kūno kultui, pastebimas valgymo sutrikimų - anoreksijos, bulimijos, persivalgymo - plitimas. Nerimą kelia šių sutrikimų pasireiškimas paauglysteje. Pastebėtina ir tai, kad paauglių berniukų mitybos sutrikimų problemos mažiau analizuojamos, palyginus su panašiomis mergai- čių problemomis, nors vis daugeja atvejų, kai mitybos sutrikimai būdingi vyriškos lyties atstovams. Vis daugiau paauglių berniukų kenčia nuo valgymo sutrikimų, kadangi paauglysteje ypač būdingas jautrumas aplinkinių pastaboms ir kritikai. Svarbu palyginti skirtingų lyčių paauglių mitybos ịpročius, siekiant įžvelgti galimas tendencijas bei numatyti galimų sutrikimų prevencijos priemones. Valgymo sutrikimai paaugliams turi daugiau neigiamų pasekmių, nei suaugusiems. Tyrimo rezultati rodo, kad paauglysteje labai svarbia tampa išvaizda, kūno formos, tinkamo svorio palaikymas. Pagrindinèmis mitybos sutrikimų priežastimis galima ịvardinti nepasitikejjimą savimi, žiniasklaidos, bendraamžių įtaką, netinkamą kūno formų vertinimą. Būtina laiku pradèti rūpintis sveikos mitybos ịūdžių formavimu, suteikiant paaugliams žinių apie jų gyvenime vykstančius fiziologinius pokyčius ir mitybos raciono reikšmę bręstančiam organizmui.

Deja, tenka konstatuoti, kad Lietuvoje, kaip ir kitose Europos Sajungos šalyse, auga skaičius gyventojų, turinčių antsvorio ir nutukimo problemų. Dèl netinkamos mitybos ịpročių ateityje gali tik padaugèti lètinių ligų, tokių kaip kraujagyslių sistemos ligos, padidèjęs kraujospūdis, antro tipo diabetas, insultas ir k.t. [4].

Sveika mityba - vienas pagrindinių sveikatą lemiančių gyvensenos veiksnių bei ligų riziką mažinančių elementų. Lietuvoje per pastaruosius du dešimtmečius ịvykusios politinès ir ekonominès permainos paveikè gyventojų mitybą. Moksliniai tyrimai pagrindžia vaikų ir paauglių, kaip ir visų gyventojų, tiesioginị ryši su ịvairiais socialiniais ir ekonominiais veiksniais: maisto produktų kaina ir jų rinkodara, sveikatai palankiu produktų prieinamumu, nedarbu, šeimos turtine padètimi, reklama ir kitais veiksniais. Skirtingai nuo suaugusių, vaiku ir paaugliu mitybą veikia dar daugiau veiksnių: gyvensenos formavimosi ypatumai, žinių ir patirties stoka, tèvų elgesio ir auklèjimo modeliai, šeimos sudètis, bendraamžių įtaka, mokyklos veikla ir strategija, sprendžiant mokinių mitybos klausimus ir kt. Tinkama mityba itin svarbi paauglystès laikotarpiu, kadangi šiuo periodu intensyviai vystosi organizmas, formuojasi ir 
ịsitvirtina sveikos gyvensenos įpročiai. Daugelyje Europos šaliu sveika mityba vertinama pagal tai, kiek gyventojai vartoja vaisių ir daržovių. Pagal Pasaulinès sveikatos organizacijos rekomendacijas, kasdien reikia suvalgyti apie 400 gramų ịvairių vaisių ir daržovių, be bulvių. Pagal ši kriterijų išanalizavus mokinių maitinimosi ypatumus, buvo nustatyta, kad vaisius ir daržoves kasdien valgo mažiau nei trečdalis mokinių; vyresnio amžiaus mokiniai vaisių ir daržovių valgo rečiau, nei jaunesnio amžiaus mokiniai; kaime gyvenantys mokiniai daržovių valgo daugiau, nei gyvenantys mieste, tačiau - mažai valgo vaisių; didesnę galimybę valgyti vaisius ir daržoves turi turtingesnès šeimos; per aštuonis metus galimybè valgyti vaisius ir daržoves tarp berniukų sumažejo, o mergaičių - nepakito [2].

Pasaulio sveikatos organizacija mitybos įtaką žmonių sveikatai priskiria prie keturių svarbiausių veiksnių. Lietuvos gyventojų sveikatos rodikliai, kuriuos nulemia neteisinga mityba ir nepalanki sveikatai maisto produktų sudètis, deja, tebèra blogi [1].

Svarbu pastebėti, kad mitybos ịpročiai susiformuoja dar vaikystejje, bet jie gali kisti, keičiantis socialinei padéčiai kuo ji aukštesnè, tuo sveikesniais tampa ir mitybos ịpročiai.

Moksliniais tyrimais ịrodyta, kad vaikystejje susiformavę ịpročiai daugeliui lieka ir visam gyvenimui. Todèl, formuojant sveikos gyvensenos ịpročius, svarbu nuo pat mažens ugdyti supratimą apie sveiką ir subalansuotą mitybą. Didžiausios įtakos vaiko gyvensenai darantys asmenys - tèvai - turètų atkreipti ypatingą dèmesị ị augančio vaiko mitybą ir kitus sveikos gyvensenos aspektus [5].

Tyrimo tikslas - palyginti skirtingų lyčių paauglių mitybos itpročius.

\section{Tyrimo metodika}

Tyrimo kontingentas: penktų, septintų, devintų klasių 10 Utenos regiono mokyklų moksleiviai. Suvedant tyrimo rezultatus, tiriamieji buvo suskirstyti i dvi grupes pagal lytị. Straipsnio autorès tyrimo rezultatus pateikè lentelèse. Iš viso tyrime dalyvavo $272-5-7$ klasiu mokiniai ir 147 - 9 klasių mokiniai. Tyrime dalyvavusios mokyklos buvo atrinktos atsitiktinès atrankos būdu. 5 - 7 klasių tiriamuju kontingentą sudare 129 berniukai ir 143 mergaitès, o 9 klasių -83 berniukai ir 64 mergaitès. Taikytas tyrimo metodas - anoniminè anketinè apklausa, naudojant standartizuotą klausimyną, sudarytą iš 101 klausimo. Šiam straipsniui buvo atrinkti tik tų klausimų atsakymų rezultatai, kurie leido atskleisti mitybos ịpročių skirtumus ir tapatumus paauglių lyčių atžvilgiu. Buvo taikoma tarptautinès studijos „Mokyklinio amžiaus vaikų gyvensenos ir sveikatos tyrimas - HBSC" metodologija. Tyrimo programą koordinavo PSO (Healfh Behaviour in School - Aged Children

\begin{tabular}{|c|c|c|c|c|c|c|c|c|c|c|}
\hline \multirow[t]{2}{*}{ Teiginiai } & \multirow[t]{2}{*}{ Lytis } & \multicolumn{2}{|c|}{ Kas dieną } & \multicolumn{2}{|c|}{$\begin{array}{l}\text { 3-4 kartus } \\
\text { per savaitę }\end{array}$} & \multicolumn{2}{|c|}{$\begin{array}{l}\text { 1-2 kartus } \\
\text { per savaitę }\end{array}$} & \multicolumn{2}{|c|}{$\begin{array}{c}\text { Retai arba } \\
\text { niekada }\end{array}$} & \multirow[b]{2}{*}{$\mathbf{p}$} \\
\hline & & Sk. & $\%$ & Sk. & $\%$ & Sk. & $\%$ & Sk. & $\%$ & \\
\hline \multirow{2}{*}{$\begin{array}{l}\text { Šiltus pusryčius arba pietus } \\
\text { mokyklos valgykloje }\end{array}$} & Bern. & 49 & 40,8 & 19 & 15,8 & 19 & 15,8 & 33 & 27,5 & \multirow[t]{2}{*}{0,691} \\
\hline & Merg. & 62 & 44,9 & 22 & 15,9 & 15 & 10,9 & 39 & 28,3 & \\
\hline \multirow{2}{*}{$\begin{array}{l}\text { Lengvus užkandžius } \\
\text { mokykloje }\end{array}$} & Bern. & 22 & 18,3 & 25 & 20,8 & 31 & 25,8 & 42 & 35,0 & \multirow[t]{2}{*}{0,069} \\
\hline & Merg. & 12 & 9,1 & 21 & 15,9 & 47 & 35,6 & 52 & 39,4 & \\
\hline \multirow{2}{*}{$\begin{array}{l}\text { Iš namų ị mokyklą atsineštą } \\
\text { sumuštinị }\end{array}$} & Bern. & 3 & 2,8 & 0 & 0,0 & 2 & 1,8 & 104 & 95,4 & \multirow[t]{2}{*}{$0,044 *$} \\
\hline & Merg. & 0 & 0,0 & 3 & 2,3 & 7 & 5,3 & 122 & 92,4 & \\
\hline \multirow{2}{*}{$\begin{array}{l}\text { Saldainius, sausainius, } \\
\text { traškučius pertraukų metu }\end{array}$} & Bern. & 6 & 5,3 & 9 & 7,9 & 26 & 22,8 & 73 & 64,0 & \multirow[t]{2}{*}{0,350} \\
\hline & Merg. & 3 & 2,3 & 6 & 4,5 & 37 & 28,0 & 86 & 65,2 & \\
\hline \multirow{2}{*}{$\begin{array}{l}\text { Obuolius arba kitus vaisius } \\
\text { pertraukų metu }\end{array}$} & Bern. & 4 & 3,5 & 8 & 7,1 & 22 & 19,5 & 79 & 69,9 & \multirow[t]{2}{*}{$0,001^{*}$} \\
\hline & Merg. & 4 & 3,0 & 17 & 12,9 & 52 & 39,4 & 59 & 44,7 & \\
\hline
\end{tabular}

- HBSC), Kopenhaga, Danija. Tyrimo rezultatai apdoroti, naudojant aprašomosios statistinès analizès metodus, taikant statistinès duomenų analizès programą SPSS 10.1.0. bei EXCEL programą. Pasirinkti trys reikšmingumo lygiai: ${ }^{*}$-p $<0,05$ - patikima; $* *-p<0,01-$ labai patikima; $* * *$ _ $\mathrm{p}<0,001-$ ypač patikima.

\section{Tyrimo rezultatai ir jų aptarimas}

Suprantama, kad sveikata daugiausia priklauso nuo žmogaus gyvensenos. Mityba yra vienas svarbiausių gyvensenos

2 lentelè. Patiekalų pasirinkimo valgykloje kriterijai $*_{p}<0,05$

\begin{tabular}{|c|c|c|c|c|c|c|c|c|c|c|}
\hline \multirow[t]{2}{*}{ Teiginiai } & \multirow[t]{2}{*}{ Lytis } & \multicolumn{2}{|c|}{$\begin{array}{l}\text { Labai } \\
\text { dažnai }\end{array}$} & \multicolumn{2}{|c|}{ Dažnai } & \multicolumn{2}{|c|}{ Retai } & \multicolumn{2}{|c|}{ Niekada } & \multirow[b]{2}{*}{ p } \\
\hline & & Sk. & $\%$ & Sk. & $\%$ & Sk. & $\%$ & Sk. & $\%$ & \\
\hline \multirow[t]{2}{*}{ Kainą } & Bern. & 19 & 15,8 & 30 & 25,0 & 44 & 36,7 & 27 & 22,5 & \multirow[t]{2}{*}{0,544} \\
\hline & Merg. & 14 & 10,9 & 40 & 31,0 & 44 & 34,1 & 31 & 24,0 & \\
\hline \multirow[t]{2}{*}{ Išvaizdą } & Bern. & 17 & 14,2 & 37 & 30,8 & 37 & 30,8 & 29 & 24,2 & \multirow[t]{2}{*}{0,056} \\
\hline & Merg. & 26 & 20,2 & 51 & 39,5 & 36 & 27,9 & 16 & 12,4 & \\
\hline \multirow[t]{2}{*}{ Porcijos dydi } & Bern. & 25 & 20,8 & 45 & 37,5 & 29 & 24,2 & 21 & 17,5 & \multirow[t]{2}{*}{$0,001^{*}$} \\
\hline & \begin{tabular}{|l|} 
Merg. \\
\end{tabular} & 11 & 8,6 & 38 & 29,7 & 58 & 45,3 & 21 & 16,4 & \\
\hline \multirow{2}{*}{$\begin{array}{l}\text { Naudingumą } \\
\text { sveikatai }\end{array}$} & Bern. & 14 & 11,8 & 28 & 23,5 & 45 & 37,8 & 32 & 26,9 & \multirow[t]{2}{*}{0,914} \\
\hline & Merg. & 18 & 13,8 & 28 & 21,5 & 52 & 40,0 & 32 & 24,6 & \\
\hline \multirow[t]{2}{*}{ Skoni } & Bern. & 69 & 57,5 & 34 & 28,3 & 7 & 5,8 & 10 & 8,3 & \multirow[t]{2}{*}{0,621} \\
\hline & Merg. & 81 & 62,8 & 36 & 27,9 & 6 & 4,7 & 6 & 4,7 & \\
\hline
\end{tabular}

elementų, tai - sudetingas procesas, apimantis maisto medžiagu patekimą i organizmą, jų virškinimą ir įsisavinimą. Sveika mityba būtina bet kuriuo amžiaus tarpsniu, tačiau - ypač aktuali ji yra vaikystèje ir paauglystèje.

Tyrimo metu respondentų buvo klausiama, kaip dažnai jie valgo mokykloje. Beveik pusė berniukų ir mergaičių šiltus pusryčius arba pietus valgo mokyklos valgykloje, jie retai arba niekada nesineša iš namų sumuštinių. Mergaitès dažniau valgo atsineštus vaisius pertraukų metu - tai rodo, kad, norėdamos užkąsti, jos renkasi mažiau kaloringą ir organizmui naudingesni maistą, tuo tarpu daugiau nei pusė berniukų niekada ị mokyklą nesineša vaisių (1 lentelè). 
3 lentelè. Vartojamų gėrimų dažnis ${ }^{*} p<0,05$

\begin{tabular}{|c|c|c|c|c|c|c|c|c|c|c|c|c|c|c|c|c|}
\hline \multirow[t]{2}{*}{ Teiginiai } & \multirow[t]{2}{*}{ Lytis } & \multicolumn{2}{|c|}{ Niekada } & \multicolumn{2}{|c|}{$\begin{array}{c}\text { Rečiau nei } \\
\text { kartą per } \\
\text { savaitę }\end{array}$} & \multicolumn{2}{|c|}{$\begin{array}{c}\text { Kartą per } \\
\text { savaitę }\end{array}$} & \multicolumn{2}{|c|}{$\begin{array}{l}\text { 2-4 dienas } \\
\text { per savaitę }\end{array}$} & \multicolumn{2}{|c|}{$\begin{array}{l}\text { 5-6 dienas } \\
\text { per savaitę }\end{array}$} & \multicolumn{2}{|c|}{$\begin{array}{c}\text { Kartą } \\
\text { per dieną }\end{array}$} & \multicolumn{2}{|c|}{$\begin{array}{c}\text { Kelis } \\
\text { kartus } \\
\text { per } \\
\text { dieną }\end{array}$} & \multirow[b]{2}{*}{ p } \\
\hline & & Sk. & $\%$ & Sk. & $\%$ & Sk. & $\%$ & Sk. & $\%$ & Sk. & $\%$ & Sk. & $\%$ & Sk. & $\%$ & \\
\hline \multirow{2}{*}{$\begin{array}{l}\text { Šviežiai pagamintas } \\
\text { vaisių ir daržovių } \\
\text { sultis }\end{array}$} & Bern. & 21 & 16,4 & 44 & 34,4 & 27 & 21,1 & 14 & 10,9 & 5 & 3,9 & 8 & 6,3 & 9 & 7,0 & \multirow[t]{2}{*}{$0,043 *$} \\
\hline & Merg. & 33 & 23,9 & 64 & 46,4 & 21 & 15,2 & 11 & 8,0 & 3 & 2,2 & 3 & 2,2 & 3 & 2,2 & \\
\hline \multirow{2}{*}{$\begin{array}{l}\text { Namuose } \\
\text { konservuotas sultis }\end{array}$} & Bern. & 18 & 14,1 & 41 & 32,0 & 27 & 21,1 & 17 & 13,3 & 8 & 6,3 & 6 & 4,7 & 11 & 8,6 & \multirow[t]{2}{*}{0,712} \\
\hline & Merg. & 25 & 18,1 & 40 & 29,0 & 32 & 23,2 & 23 & 16,7 & 7 & 5,1 & 5 & 3,6 & 6 & 4,3 & \\
\hline \multirow{2}{*}{$\begin{array}{l}\text { Iš parduotuvès } \\
\text { nupirktas sultis } \\
\text { pakeliuose }\end{array}$} & Bern. & 11 & 8,7 & 30 & 23,6 & 38 & 29,9 & 27 & 21,3 & 6 & 4,7 & 8 & 6,3 & 7 & 5,5 & \multirow[t]{2}{*}{0,473} \\
\hline & Merg. & 12 & 8,8 & 34 & 24,8 & 28 & 20,4 & 34 & 24,8 & 14 & 10,2 & 9 & 6,6 & 6 & 4,4 & \\
\hline \multirow[t]{2}{*}{ Vandenị } & Bern. & 4 & 3,1 & 2 & 1,6 & 7 & 5,5 & 11 & 8,6 & 11 & 8,6 & 9 & 7,0 & 84 & 65,6 & \multirow[t]{2}{*}{$0,028^{*}$} \\
\hline & Merg. & 2 & 1,4 & 2 & 1,4 & 1 & 0,7 & 3 & 2,2 & 10 & 7,2 & 18 & 13,0 & 102 & 73,9 & \\
\hline \multirow{2}{*}{$\begin{array}{l}\text { Iš parduotuvės } \\
\text { nupirktą vandenị }\end{array}$} & Bern. & 53 & 41,4 & 21 & 16,4 & 23 & 18,0 & 12 & 9,4 & 5 & 3,9 & 5 & 3,9 & 9 & 7,0 & \multirow[t]{2}{*}{0,322} \\
\hline & Merg. & 58 & 42,0 & 24 & 17,4 & 13 & 9,4 & 12 & 8,7 & 12 & 8,7 & 9 & 6,5 & 10 & 7,2 & \\
\hline \multirow{2}{*}{$\begin{array}{l}\text { Kokakolą, fantą } \\
\text { ar kitus gazuotus } \\
\text { saldžius gėrimus }\end{array}$} & Bern. & 16 & 12,5 & 39 & 30,5 & 33 & 25,8 & 18 & 14,1 & 7 & 5,5 & 5 & 3,9 & 10 & 7,8 & \multirow[t]{2}{*}{$0,009^{*}$} \\
\hline & Merg. & 36 & 26,1 & 53 & 38,4 & 19 & 13,8 & 19 & 13,8 & 4 & 2,9 & 3 & 2,2 & 4 & 2,9 & \\
\hline \multirow[t]{2}{*}{ Natūralią kavą } & Bern. & 61 & 47,7 & 23 & 18,0 & 16 & 12,5 & 13 & 10,2 & 3 & 2,3 & 3 & 2,3 & 9 & 7,0 & \multirow[t]{2}{*}{0,400} \\
\hline & Merg. & 54 & 39,1 & 21 & 15,2 & 21 & 15,2 & 17 & 12,3 & 4 & 2,9 & 11 & 8,0 & 10 & 7,2 & \\
\hline \multirow{2}{*}{$\begin{array}{l}\text { Natūralų kaimišką } \\
\text { pieną }\end{array}$} & Bern. & 36 & 28,1 & 21 & 16,4 & 11 & 8,6 & 10 & 7,8 & 15 & 11,7 & 15 & 11,7 & 20 & 15,6 & \multirow{2}{*}{$0,002 *$} \\
\hline & Merg. & 49 & 35,5 & 30 & 21,7 & 18 & 13,0 & 16 & 11,6 & 4 & 2,9 & 3 & 2,2 & 18 & 13,0 & \\
\hline \multirow{2}{*}{$\begin{array}{l}\text { Parduotuveje pirktą } \\
\text { pieną }\end{array}$} & Bern. & 39 & 30,5 & 22 & 17,2 & 16 & 12,5 & 19 & 14,8 & 12 & 9,4 & 11 & 8,6 & 9 & 7,0 & \multirow[t]{2}{*}{0,890} \\
\hline & Merg. & 41 & 29,7 & 26 & 18,8 & 24 & 17,4 & 18 & 13,0 & 12 & 8,7 & 11 & 8,0 & 6 & 4,3 & \\
\hline \multirow{2}{*}{$\begin{array}{l}\text { Kefyrą, rūgpienį, } \\
\text { natūralų jogurtą }\end{array}$} & Bern. & 30 & 23,4 & 38 & 29,7 & 21 & 16,4 & 13 & 10,2 & 8 & 6,3 & 6 & 4,7 & 12 & 9,4 & \multirow[t]{2}{*}{0,550} \\
\hline & Merg. & 38 & 27,5 & 33 & 23,9 & 30 & 21,7 & 16 & 11,6 & 9 & 6,5 & 6 & 4,3 & 6 & 4,3 & \\
\hline
\end{tabular}

4 lentelè. Maisto produktų naudingumas sveikatai ${ }^{*} p<0,05$

\begin{tabular}{|c|c|c|c|c|c|c|c|c|c|c|c|c|}
\hline \multirow[t]{2}{*}{ Teiginiai } & \multirow[t]{2}{*}{ Lytis } & \multicolumn{2}{|c|}{$\begin{array}{c}\text { Visai } \\
\text { nenaudingi } \\
\text { arba žalingi }\end{array}$} & \multicolumn{2}{|c|}{$\begin{array}{c}\text { Nelabai } \\
\text { naudingi }\end{array}$} & \multicolumn{2}{|c|}{$\begin{array}{c}\text { Vidutiniškai } \\
\text { naudingi }\end{array}$} & \multicolumn{2}{|c|}{ Naudingi } & \multicolumn{2}{|c|}{$\begin{array}{c}\text { Labai } \\
\text { naudingi }\end{array}$} & \multirow{2}{*}{$\mathbf{p}$} \\
\hline & & Sk. & $\%$ & Sk. & $\%$ & Sk. & $\%$ & Sk. & $\%$ & Sk. & $\%$ & \\
\hline \multirow{2}{*}{$\begin{array}{l}\text { Šviežiai pagamintos } \\
\text { vaisių ir daržovių } \\
\text { sultys }\end{array}$} & Bern. & 5 & 3,9 & 7 & 5,5 & 12 & 9,4 & 32 & 25,2 & 71 & 55,9 & \multirow[t]{2}{*}{$0,022 *$} \\
\hline & Merg. & 1 & 0,7 & 2 & 1,4 & 5 & 3,6 & 35 & 25,4 & 95 & 68,8 & \\
\hline \multirow{2}{*}{$\begin{array}{l}\text { Kokakola, fanta ar } \\
\text { kiti gazuoti saldinti } \\
\text { gėrimai }\end{array}$} & Bern. & 71 & 55,9 & 36 & 28,3 & 10 & 7,9 & 5 & 3,9 & 5 & 3,9 & \multirow[t]{2}{*}{$0,000^{*}$} \\
\hline & Merg. & 117 & 84,8 & 16 & 11,6 & 1 & 0,7 & 2 & 1,4 & 2 & 1,4 & \\
\hline \multirow[t]{2}{*}{ Juoda rupi duona } & Bern. & 4 & 3,1 & 13 & 10,2 & 28 & 22,0 & 42 & 33,1 & 40 & 31,5 & \multirow[t]{2}{*}{0,052} \\
\hline & Merg. & 0 & 0,0 & 9 & 6,5 & 22 & 15,9 & 63 & 45,7 & 44 & 31,9 & \\
\hline \multirow[t]{2}{*}{ Balta duona, batonas } & Bern. & 5 & 3,9 & 13 & 10,2 & 47 & 36,7 & 37 & 28,9 & 26 & 20,3 & \multirow[t]{2}{*}{$0,046^{*}$} \\
\hline & Merg. & 2 & 1,5 & 26 & 19,0 & 59 & 43,1 & 35 & 25,5 & 15 & 10,9 & \\
\hline \multirow[t]{2}{*}{ Bulvių traškučiai } & Bern. & 81 & 63,3 & 27 & 21,1 & 10 & 7,8 & 4 & 3,1 & 6 & 4,7 & \multirow[t]{2}{*}{$0,000^{*}$} \\
\hline & Merg. & 121 & 87,7 & 12 & 8,7 & 2 & 1,4 & 0 & 0,0 & 3 & 2,2 & \\
\hline \multirow[t]{2}{*}{ Liesas pienas } & Bern. & 11 & 8,7 & 18 & 14,2 & 43 & 33,9 & 36 & 28,3 & 19 & 15,0 & \multirow[t]{2}{*}{0,051} \\
\hline & Merg. & 2 & 1,4 & 23 & 16,7 & 48 & 34,8 & 50 & 36,2 & 15 & 10,9 & \\
\hline \multirow{2}{*}{$\begin{array}{l}\text { Natūralus kaimiškas } \\
\text { pienas }\end{array}$} & Bern. & 3 & 2,4 & 13 & 10,2 & 15 & 11,8 & 28 & 22,0 & 68 & 53,5 & \multirow[t]{2}{*}{$0,017^{*}$} \\
\hline & Merg. & 5 & 3,6 & 5 & 3,6 & 11 & 8,0 & 53 & 38,4 & 64 & 46,4 & \\
\hline \multirow[t]{2}{*}{ Saldūs sūreliai, ledai } & Bern. & 18 & 14,2 & 45 & 35,4 & 37 & 29,1 & 16 & 12,6 & 11 & 8,7 & \multirow[t]{2}{*}{$0,036^{*}$} \\
\hline & Merg. & 12 & 8,7 & 60 & 43,5 & 51 & 37,0 & 12 & 8,7 & 3 & 2,2 & \\
\hline \multirow[t]{2}{*}{ Saldainiai } & Bern. & 41 & 32,3 & 58 & 45,7 & 15 & 11,8 & 5 & 3,9 & 8 & 6,3 & \multirow[t]{2}{*}{0,523} \\
\hline & Merg. & 50 & 36,2 & 68 & 49,3 & 13 & 9,4 & 3 & 2,2 & 4 & 2,9 & \\
\hline
\end{tabular}

tojamo maisto skonis svarbus abiejų lyčių tiriamiesiems (2 lentelè). Tyrimas atskleidè, kad statistiškai reikšmingai pagal lytị skiriasi šviežiai pagamintų vaisių ar daržovių sulčių gèrimo dažnumo pasiskirstymas $(p<0,05)$, vandens gërimo dažnumo pasiskirstymas $(\mathrm{p}<0,05)$, Kokakolos, fantos ar kitų gazuotų saldžių gėrimų gèrimo dažnumo pasiskirstymas $(p<0,05)$ bei natūralaus kaimiško pieno gérimo dažnumo pasiskirstymas $(\mathrm{p}<0,05)$. Šviežiai pagamintų vaisių ar daržovių sultis dažniau geria berniukai. Tuo tarpu dauguma mergaičių minètus gèrimus vartoja rečiau nei kartą per savaitę. Vandenị dažniau geria mergaitès (net kelis kartus per dieną), tuo tarpu berniukai - tik 2 -4 dienas per savaitę. Kokakolą, fantą ar kitus gazuotus saldžius gėrimus dažniau geria berniukai, nemažai jų tai daro net kelis kartus per dieną, tuo tarpu beveik pusė mergaičių šiuos gérimus vartoja rečiau nei kartą per savaitę. Nors berniukai mažai geria vandens bei pernelyg dažnai vartoja saldžiuosius gazuotus gérimus, tačiau jų natūralaus kaimiško pieno vartojimo rodikliai yra geresni: nemaža dalis jų pieną geria kartą ar net kelis kartus per dieną, beveik pusė mergaičiu pieno negeria niekada (3 lentelè). Paklausus moksleivių, kiek, jų nuomone, sveikatai yra naudingi tokie gerimai ir maisto produktai kaip kokakola, fanta ir kiti gazuoti saldinti gèrimai, bulviu traškučiai bei saldūs sūreliai ir ledai, balta duona ir batonas - paaiškejjo, kad mergaitès labiau įžvelgia jų žalą sveikatai $(p<0,05)$. Šviežiai pagamintų vaisių ar daržovių sultis

Tyrimas parodè, kad berniukai mokyklos valgykloje renkasi patiekalus, atsižvelgdami i porcijos dydi $(\mathrm{p}<0,05)$, tuo tarpu mergaitès - tai daro retai (joms ypač svarbi patiekalo išvaizda), tikètina, kad berniukai yra aktyvesni - išeikvoja daugiau energijos ir su maistu jos turi gauti daugiau. Var- labiau vertina mergaitės $(p<0,05)$. Tai leidžia teigti, kad mergaites daugiau žino apie maisto vertę bei ịtaką organizmui. Tačiau natūralaus kaimiško pieno naudingumas labiau vertinamas berniukų $(\mathrm{p}<0,05)$ (šie rezultatai patvirtino ir anksčiau gautus, kuomet paaiškèjo, kad jie dažniau geria 
natūralų kaimišką pieną) (4 lentelè). Mergaičių mažesnis natūralaus kaimiško pieno suvartojimas gali būti paaiškinamas ir jo didelio kaloringumo prasme, kuris ypač aktualus paauglèms, kritiškai vertinančioms savo kūno pokyčius.

İvertinanat saldumynų poveikị organizmui, moksleiviu nuomonès išsiskiria: berniukai akcentuoja neigiamus fiziologinius padarinius (dantims, pilvui, galvai), tuo tarpu mergaitems svarbiau išvaizdos pokyčiai (nutukimo rizika) (5 lentelè).

Paauglystès laikotarpiu organizmas intensyviai auga ir vystosi, energijos poreikiai santykinai yra žymiai didesni, negu suaugusiųų̨: medžiagų apykaita intensyvesnè, jie yra judresni, todèl sunaudoja daugiau energijos. Daug energijos reikia ir itemptam protiniam darbui, mokantis. Pastebètina, kad vaiko organizmas jautriau reaguoja i ịvairių

5 lentelè. Neigiamo saldumynų poveikio sveikatai galimybès $p=0,000^{*}$

\begin{tabular}{|l|c|c|c|c|c|c|}
\hline \multirow{2}{*}{ Teiginiai } & \multicolumn{2}{|c|}{ Berniukai } & \multicolumn{2}{c|}{ Mergaitès } & \multicolumn{2}{c|}{ Iš viso } \\
\cline { 2 - 7 } & Sk. & $\mathbf{\%}$ & Sk. & $\mathbf{\%}$ & Sk. & $\mathbf{\%}$ \\
\hline Gali sugesti dantys & 54 & 46,2 & 47 & 35,9 & 101 & 40,7 \\
\hline Galima nutukti & 38 & 32,5 & 74 & 56,5 & 112 & 45,2 \\
\hline Gali pradèti skaudèti pilvą & 6 & 5,1 & 6 & 4,6 & 12 & 4,8 \\
\hline Gali pradèti skaudèti galvą & 4 & 3,4 & 0 & 0,0 & 4 & 1,6 \\
\hline Nežinau & 15 & 12,8 & 4 & 3,1 & 19 & 7,7 \\
\hline
\end{tabular}

6 lentelè. Maisto produktų valgymo dažnis (2) ${ }^{*} p<0,05$

\begin{tabular}{|c|c|c|c|c|c|c|c|c|c|c|c|c|c|c|c|c|}
\hline \multirow[t]{2}{*}{ Teiginiai } & & \multicolumn{2}{|c|}{ Niekada } & \multicolumn{2}{|c|}{$\begin{array}{c}\text { Rečiau nei } \\
\text { kartą per } \\
\text { savaitę }\end{array}$} & \multicolumn{2}{|c|}{$\begin{array}{c}\text { Kartą per } \\
\text { savaitę }\end{array}$} & \multicolumn{2}{|c|}{$\begin{array}{c}\text { 2-4 dienas } \\
\text { per savaitę }\end{array}$} & \multicolumn{2}{|c|}{$\begin{array}{l}\text { 5-6 dienas } \\
\text { per savaitę }\end{array}$} & \multicolumn{2}{|c|}{$\begin{array}{c}\text { Kartą per } \\
\text { dieną }\end{array}$} & \multicolumn{2}{|c|}{$\begin{array}{c}\text { Kelis kartus } \\
\text { per dieną }\end{array}$} & \multirow[b]{2}{*}{$\mathbf{p}$} \\
\hline & & Sk. & $\%$ & Sk. & $\%$ & Sk. & $\%$ & Sk. & $\%$ & Sk. & $\%$ & Sk. & $\%$ & Sk. & $\%$ & \\
\hline \multirow[t]{2}{*}{ Juodą duoną } & Bern. & 15 & 11,9 & 7 & 5,6 & 12 & 9,5 & 26 & 20,6 & 16 & 12,7 & 14 & 11,1 & 36 & 28,6 & \multirow[t]{2}{*}{$0,031 *$} \\
\hline & Merg. & 13 & 9,4 & 22 & 15,9 & 17 & 12,3 & 21 & 15,2 & 15 & 10,9 & 25 & 18,1 & 25 & 18,1 & \\
\hline \multirow[t]{2}{*}{ Baltą duoną, batoną } & Bern. & 2 & 1,6 & 11 & 8,7 & 11 & 8,7 & 20 & 15,7 & 25 & 19,7 & 19 & 15,0 & 39 & 30,7 & \multirow[t]{2}{*}{0,120} \\
\hline & Merg. & 9 & 6,5 & 11 & 8,0 & 8 & 5,8 & 24 & 17,4 & 24 & 17,4 & 33 & 23,9 & 29 & 21,0 & \\
\hline \multirow[t]{2}{*}{ Manų košę } & Bern. & 19 & 15,1 & 46 & 36,5 & 33 & 26,2 & 12 & 9,5 & 10 & 7,9 & 1 & 0,8 & 5 & 4,0 & \multirow[t]{2}{*}{0,058} \\
\hline & Merg. & 26 & 18,8 & 70 & 50,7 & 24 & 17,4 & 12 & 8,7 & 4 & 2,9 & 1 & 0,7 & 1 & 0,7 & \\
\hline \multirow{2}{*}{$\begin{array}{l}\text { Kitokių kruopu } \\
\text { košes }\end{array}$} & Bern. & 14 & 11,0 & 38 & 29,9 & 32 & 25,2 & 19 & 15,0 & 12 & 9,4 & 4 & 3,1 & 8 & 6,3 & \multirow[t]{2}{*}{0,350} \\
\hline & Merg. & 13 & 9,4 & 47 & 34,1 & 37 & 26,8 & 27 & 19,6 & 8 & 5,8 & 4 & 2,9 & 2 & 1,4 & \\
\hline \multirow[t]{2}{*}{ Varškę, sūrị } & Bern. & 9 & 7,0 & 21 & 16,4 & 28 & 21,9 & 33 & 25,8 & 15 & 11,7 & 14 & 10,9 & 8 & 6,3 & \multirow[t]{2}{*}{0,669} \\
\hline & Merg. & 7 & 5,1 & 23 & 16,7 & 37 & 26,8 & 39 & 28,3 & 14 & 10,1 & 15 & 10,9 & 3 & 2,2 & \\
\hline \multirow{2}{*}{$\begin{array}{l}\text { Saldžius sūrelius, } \\
\text { jogurto gèrimus, } \\
\text { ledus }\end{array}$} & Bern. & 5 & 3,9 & 31 & 24,2 & 20 & 15,6 & 29 & 22,7 & 21 & 16,4 & 10 & 7,8 & 12 & 9,4 & \multirow[t]{2}{*}{0,613} \\
\hline & Merg. & 4 & 2,9 & 28 & 20,3 & 28 & 20,3 & 37 & 26,8 & 23 & 16,7 & 12 & 8,7 & 6 & 4,3 & \\
\hline \multirow[t]{2}{*}{ Saldainius, šokoladą } & Bern. & 2 & 1,6 & 26 & 20,5 & 37 & 29,1 & 29 & 22,8 & 14 & 11,0 & 6 & 4,7 & 13 & 10,2 & \multirow[t]{2}{*}{0,298} \\
\hline & Merg. & 6 & 4,3 & 26 & 18,8 & 27 & 19,6 & 37 & 26,8 & 22 & 15,9 & 10 & 7,2 & 10 & 7,2 & \\
\hline \multirow{2}{*}{$\begin{array}{l}\text { Tortą, pyragaičius, } \\
\text { sausainius }\end{array}$} & Bern. & 6 & 4,7 & 43 & 33,9 & 34 & 26,8 & 20 & 15,7 & 10 & 7,9 & 7 & 5,5 & 7 & 5,5 & 0,578 \\
\hline & Merg. & 12 & 8,7 & 50 & 36,2 & 37 & 26,8 & 24 & 17,4 & 7 & 5,1 & 4 & 2,9 & 4 & 2,9 & \\
\hline Traškučius & Bern. & 22 & 17,3 & 44 & 34,6 & 30 & 23,6 & 9 & 7,1 & 9 & 7,1 & 8 & 6,3 & 5 & 3,9 & 0,183 \\
\hline $\begin{array}{l}\text { (kukurūzų, keptų } \\
\text { bulvių) }\end{array}$ & Merg. & 22 & 15,9 & 62 & 44,9 & 29 & 21,0 & 15 & 10,9 & 4 & 2,9 & 3 & 2,2 & 3 & 2,2 & \\
\hline Greito maisto & Bern. & 27 & 21,3 & 53 & 41,7 & 16 & 12,6 & 15 & 11,8 & 6 & 4,7 & 2 & 1,6 & 8 & 6,3 & $0,028^{*}$ \\
\hline produktus & Merg. & 38 & 27,5 & 66 & 47,8 & 22 & 15,9 & 7 & 5,1 & 2 & 1,4 & 2 & 1,4 & 1 & 0,7 & \\
\hline Žuvị & Bern. & 24 & 18,8 & 41 & 32,0 & 33 & 25,8 & 11 & 8,6 & 8 & 6,3 & 5 & 3,9 & 6 & 4,7 & 0,116 \\
\hline & Merg. & 36 & 26,1 & 52 & 37,7 & 35 & 25,4 & 8 & 5,8 & 3 & 2,2 & 3 & 2,2 & 1 & 0,7 & \\
\hline Žuvies produktus & Bern. & 22 & 17,5 & 40 & 31,7 & 38 & 30,2 & 8 & 6,3 & 5 & 4,0 & 7 & 5,6 & 6 & 4,8 & $0,046^{*}$ \\
\hline & Merg. & 33 & 23,9 & 56 & 40,6 & 34 & 24,6 & 9 & 6,5 & 4 & 2,9 & 1 & 0,7 & 1 & 0,7 & \\
\hline Virtą, keptą mésą & Bern. & 1 & 0,8 & 7 & 5,6 & 18 & 14,4 & 39 & 31,2 & 26 & 20,8 & 18 & 14,4 & 16 & 12,8 & $0,012 *$ \\
\hline & Merg. & 8 & 5,8 & 12 & 8,7 & 19 & 13,8 & 35 & 25,4 & 38 & 27,5 & 22 & 15,9 & 4 & 2,9 & \\
\hline Sardeles, pieniškas & Bern. & 14 & 10,9 & 35 & 27,3 & 31 & 24,2 & 25 & 19,5 & 12 & 9,4 & 2 & 1,6 & 9 & 7,0 & 0,107 \\
\hline dešreles & Merg. & 27 & 19,6 & 46 & 33,3 & 29 & 21,0 & 15 & 10,9 & 13 & 9,4 & 4 & 2,9 & 4 & 2,9 & \\
\hline Rūkytą kumpì, & Bern. & 2 & 1,6 & 13 & 10,2 & 29 & 22,8 & 42 & 33,1 & 14 & 11,0 & 12 & 9,4 & 15 & 11,8 & $0,000^{*}$ \\
\hline & Merg. & 17 & 12,3 & 31 & 22,5 & 32 & 23,2 & 33 & 23,9 & 15 & 10,9 & 6 & 4,3 & 4 & 2,9 & \\
\hline Kiaušinius & Bern. & 9 & 7,1 & 20 & 15,7 & 38 & 29,9 & 26 & 20,5 & 17 & 13,4 & 10 & 7,9 & 7 & 5,5 & $0,037 *$ \\
\hline & Merg. & 14 & 10,1 & 44 & 31,9 & 35 & 25,4 & 25 & 18,1 & 10 & 7,2 & 6 & 4,3 & 4 & 2,9 & \\
\hline
\end{tabular}

maisto medžiagų trūkumą ar perteklių, lengviau pažeidžiami jo virškinimo organai. Nevisavertè ar neteisingai organizuota mityba sutrikdo augimą, sumažina pasipriešinimą nepalankiems aplinkos veiksniams ir ligoms. Gydytojai ir mitybos specialistai su prasta mityba sieja daugybę žmogaus ligų: širdies ir kraujagyslių sistemos, onkologines, medžiagų apykaitos, virškinimo organų ir t.t. Gauti rezultatai parodè, kad statistiškai reikšmingai pagal lyti skiriasi juodos duonos valgymo dažnumo pasiskirstymas $(p<0,05)$, greito maisto produktų valgymo dažnumo pasiskirstymas $(p<0,05)$, žuvies produktų valgymo dažnumo pasiskirstymas $(p<0,05)$, virtos, keptos mėsos valgymo dažnumo pasiskirstymas $(p<0,05)$, rūkyto kumpio, rūkytos dešros valgymo dažnumo pasiskirstymas $(p<0,05)$ bei kiaušinių valgymo dažnumo pasiskirstymas $(\mathrm{p}<0,05)$ (6 lentelè). Pastebètini skirtumai, vartojant greito maisto produktus: daugiau mergaičių nei berniukų jų niekada nevartoja; taip pat - daugiau jų rečiau nei kartą per savaitę vartoja greitą maistą; berniukai labiau linkę vartoti tokị maistą - tam tikra jų dalis vartoja 2-4 dienas per savaitę, o kai kurie - net kelis kartus per dieną. Šie rezultatai leidžia iž̌velgti galimą netinkamų mitybos ịpročių susiformavimo riziką, kuri vèliau gali sąlygoti rimtesnius - anksčiau minètus - sveikatos sutrikimus. Tai pasakytina ir vertinant tokių maisto produktu kaip kepta ir virta mèsa, rūkytas kumpis, dešra ir kiaušiniai berniukų vartojimo dažnị. Tačiau išsiskiria berniukų žuvies produktų vartojimo dažnis: jie žuvị vartoja dažiau nei mergaitès - tai vertintina ypač pozityviai, suvokiant žuvies produktų naudą organizmui.

Paaugliu mitybos sutrikimai gana dažnas reiškinys. Vis daugiau paauglių, besirūpindami savo kūno grožiu, pradeda skaičiuoti kalorijas, laikytis dietu, intensyviai sportuoti. Yra nemažai aplinkos veiksnių, kurie turi įtakos paaugliu mitybos sutrikimams. Išskirtini keli pagrindiniai: pirma - bendraamžių įtaka, kuri paauglysteje pati svarbiausia, antra, bet nemažiau svarbi - žiniasklaidos įtaka, kuri visokiomis formomis demonstruoja, kaip turi atrodyti, jų nuomone, gražus žmogus. $\mathrm{Na}$ ir trečias veiksnys, tai - paauglių žemas savęs vertinimas. Nors tyrimu ir nustatyta, kad mergaitès dažniau nei berniukai laikosi dietos, 
tačiau tiek berniukai, tiek mergaitès akcentavo, kad svarbu nepersivalgyti ir daugiau judèti, norint numesti svorị. Berniukai dar atkreipé dèmesị ị tokias svorio metimo priemones, kaip: nevalgymą vakare bei vaistų, skirtų svorio reguliavimui, vartojimą (7, 8 lentelès). Rezultatai parodé, kad

7 lentelè. Svorio mažinimo būdai $p=0,046^{*}$

\begin{tabular}{|l|c|c|c|c|c|c|}
\hline \multirow{2}{*}{ Teiginiai } & \multicolumn{2}{|c|}{ Berniukai } & \multicolumn{2}{|c|}{ Mergaitès } & \multicolumn{2}{|c|}{ Iš viso } \\
\cline { 2 - 7 } & Sk. & $\mathbf{\%}$ & Sk. & \% & Sk. & \% \\
\hline $\begin{array}{l}\text { Gerti svorio reguliavimui } \\
\text { skirtus vaistus }\end{array}$ & 4 & 3,2 & 1 & 0,8 & 5 & 2,0 \\
\hline $\begin{array}{l}\text { Nepersivalgyti ir daugiau } \\
\text { judėti }\end{array}$ & 92 & 73,0 & 106 & 87,6 & 198 & 80,2 \\
\hline $\begin{array}{l}\text { Laikytis labai griežtos } \\
\text { (bado) dietos }\end{array}$ & 8 & 6,3 & 6 & 5,0 & 14 & 5,7 \\
\hline Nevalgyti vakare & 9 & 7,1 & 4 & 3,3 & 13 & 5,3 \\
\hline Nežinau & 13 & 10,3 & 4 & 3,3 & 17 & 6,9 \\
\hline
\end{tabular}

8 lentelè. Pastaruoju metu naudojami svorio mažinimo būdai $p=0,002$ *

\begin{tabular}{|l|c|c|c|c|c|c|}
\hline \multirow{2}{*}{ Teiginiai } & \multicolumn{2}{|c|}{ Berniukai } & \multicolumn{2}{|c|}{ Mergaitės } & \multicolumn{2}{|c|}{ Iš viso } \\
\cline { 2 - 8 } & Sk. & \% & Sk. & \% & Sk. & \% \\
\hline Ne, nes mano svoris normalus & 65 & 50,8 & 53 & 38,4 & 118 & 44,4 \\
\hline $\begin{array}{l}\text { Ne, bet man reiketų numesti } \\
\text { Svorio }\end{array}$ & 15 & 11,7 & 30 & 21,7 & 45 & 16,9 \\
\hline $\begin{array}{l}\text { Ne, nes man reikėtų priaugti } \\
\text { svorio }\end{array}$ & 27 & 21,1 & 15 & 10,9 & 42 & 15,8 \\
\hline Taip & 21 & 16,4 & 40 & 29,0 & 61 & 22,9 \\
\hline
\end{tabular}

9 lentelè. Rūpinimosi savo sveikata ir svorio priklausomybe் $*_{p}<0,05$

\begin{tabular}{|l|c|c|}
\hline \multirow{2}{*}{ Teiginys } & \multicolumn{2}{|c|}{ Svoris } \\
\cline { 2 - 3 } & $\begin{array}{c}\text { koreliacijos } \\
\text { koeficientas }\end{array}$ & $\begin{array}{c}\mathbf{p} \\
\text { reikšmė }\end{array}$ \\
\hline $\begin{array}{l}\text { Ar rūpiniesi savo } \\
\text { sveikata? }\end{array}$ & $0,179^{*}$ & 0,006 \\
\hline
\end{tabular}

10 lentelè. Sportavimo ir mankštinimosi reikšmè svorio mažinimui (6) $*_{p}<0,05$

\begin{tabular}{|l|c|c|}
\hline \multirow{2}{*}{ Teiginys } & \multicolumn{2}{|c|}{ Svoris } \\
\cline { 2 - 3 } & $\begin{array}{c}\text { koreliacijos } \\
\text { koeficientas }\end{array}$ & $\begin{array}{c}\mathbf{p} \\
\text { reikšmė }\end{array}$ \\
\hline Mankštinimasis & $-0,133^{*}$ & 0,041 \\
\hline
\end{tabular}

11 lentelè. Mokinių rūpinimosi sveikata ir sveikatos pojūčio santykis ${ }^{*} p<0,05$

\begin{tabular}{|l|c|c|}
\hline \multirow{2}{*}{ Teiginys } & \multicolumn{2}{|c|}{ Rūpinimasis sveikata } \\
\cline { 2 - 3 } & $\begin{array}{c}\text { koreliacijos } \\
\text { koeficientas }\end{array}$ & $\begin{array}{c}\mathbf{p} \\
\text { reikšmė }\end{array}$ \\
\hline $\begin{array}{l}\text { Sveikatos } \\
\text { apibūdinimas }\end{array}$ & $0,220^{*}$ & 0,000 \\
\hline
\end{tabular}

12 lentelè. Sveikatos ir laimès pojūčio santykis ${ }^{*} p<0,05$

\begin{tabular}{|l|c|c|}
\hline \multirow{2}{*}{ Teiginys } & \multicolumn{2}{|c|}{ Laimingumas } \\
\cline { 2 - 3 } & $\begin{array}{c}\text { koreliacijos } \\
\text { koeficientas }\end{array}$ & p reikšmė \\
\hline Sveikata & $0,319^{*}$ & 0,000 \\
\hline
\end{tabular}

paaugliai žino svorio reguliavimo būdus, tik atkreiptinas dẻmesys ị tai, kad jų žavèjimasis dietomis - ypač žalingas besiformuojančiam organizmui.

Gilinantis ị berniukų ir mergaičiu mitybos ypatumus, nustatytas statistiškai reikšmingas ryšys tarp mokinių svorio ir rūpinimosi sveikata $(p<0,05)$. Kuo mokiniai labiau rūpinasi savo sveikata, tuo jų svoris mažesnis ir atvirkščiai (9 lentelè). Buvo svarbu sužinoti, kaip mokinių fizinis aktyvumas lemia jų svorị. Nustatytas statistiškai reikšmingas ryšys tarp mokinių svorio ir mankštinimosi $(\mathrm{p}<0,05)$. Pastebèta, kad: kuo mokiniai rečiau sportuoja, tuo jų svoris būna didesnis (10 lentelè).

Moksleivių buvo klausiama, kaip jie apibūdintų savo sveikatą. Nustatytas statistiškai reikšmingas ryšys tarp mokinių sveikatos ir rūpinimosi sveikata $(p<0,05)$. Kuo mokiniai labiau rūpinasi savo sveikata, tuo ji geresnè ir atvirkščiai (11 lentelè). Taip pat tyrimas parodè, kad: kuo mokinių sveikata geresnè, tuo jie laimingesni (12 lentelè). Tyrimai rodo, kad žmogaus sveikata yra vienas iš stipriausių laimès veiksnių. Tačiau ryšys tarp sveikatos ir laimès sudètingas. Tam tikrų tyrimų rezultatai rodo nedidelị ryšị tarp objektyviosios (mediku ịvertintos) žmogaus sveikatos ir laimès. Gerą savijautą lemia subjektyvi sveikata - tai, kaip mes patys ją „matome“. Neigiami sveikatos pokyčiai turi laikiną neigiamą įtaką laimei. Silpna sveikata paveikia beveik visus gyvenimo aspektus: savarankiškumą, įvaizdį, asmeninius santykius, sugebejimą dirbti ir atlikti pagrindinius kasdieninius darbus. Vis dèlto, kai sveikatos pokytis stiprus (pavyzdžiui, chroniškas skausmas ar igyjama daug negalių), poveikis laimei gali būti ilgalaikis. Taigi laimei įtakos turi ir fizine, ir emocinè sveikata. Nuotaikų sutrikimai mažina gyvenimo kokybę net labiau nei chroniški fiziniai negalavimai [6].

\section{Išvados}

1. Palyginus skirtingų lyčių paauglių mitybos ịpročius, teigtina, kad: negalima kategoriškai akcentuoti, jog vaikinų ar merginų mityba yra taisyklingesnè, kadangi vienais aspektais išryškejja vienų, o jau kitais - kitų tiriamųjų mitybos ịpročiu taisyklingumas:

- merginos dažniau nei vaikinai pertraukų metu užkandžiauja atsineštais ì mokyklą vaisiais, dažniau geria vandeni, neigiamai vertina tokių maisto produktų kaip bulvių traškučiai, saldūs sūreliai, ledai, balta duona poveikị organizmui, tai rodo jų rūpinimąsi sveikata;

- vaikinai pertraukų metu linkę užkandžiauti iš namų atsineštais sumuštiniais, patiekalus rinktis pagal porcijos dydị, tačiau - jie dažniau geria šviežiai pagamintas vaisių ar daržovių sultis, pastebėtinas ir dažnesnis jų saldžiųjų gazuotų gérimų dažnesnis vartojimas - tai rodo jų gėrimų 
rinkimąsi labiau pagal skonį, nevertinant žalos organizmui. Tačiau jie dažniau geria natūralų kaimišką pieną, galbūt taip besirūpindami savo išvaizda;

- vertindami saldumynų poveikị organizmui, berniukai labiau akcentuoja neigiamus fiziologinius padarinius, tuo tarpu mergaitèms svarbiau galimi neigiami išvaizdos pokyčiai;

- merginos renkasi mažiau kaloringą maistą, o berniukai, nors ir dažniau valgo keptą, virtą mèsą, rūkytą kumpị, dešrą, tačiau dažniau valgo žuvị;

- nors mergaitès dažniau nei berniukai laikosi dietos, tačiau visi akcentavo, kad svarbu nepersivalgyti ir daugiau judèti. Berniukai nurodè, kad svarbu nevalgyti vakare, jiems taip pat žinoma svorio kontrolès priemonè - specialių vaistų vartojimas.

2. Mitybos ịpročiai sparčiai formuojasi paauglystejje, yra tiesiogiai susiję su kintančia paauglių gyvensena bei socialine aplinka ir gali turèti tiesioginès įtakos jų sveikatai ateityje. Todèl ypač svarbu tinkamos mitybos ịpročių formavimu reikiamai rūpintis tiek individuliai - šeimos, kurioje auga paauglys, tiek mokyklos - kasdieninès mokinio aplinkos, tiek visuomeniniu lygmenimis.

\section{Literatūra}

1. Zaborskis A, Lagūnaite R, Busha R, Lubienè J. Trend in eating habits among Lithuanian school-aged children in context of social inequality: three cross-sectional surveys 2002, 2006 and 2010. BMC Public Health. 2012 Jan 19;12:52.

2. Zaborskis A., Raskilas A. Lietuvos mokinių fizinio aktyvumo pokyčiai 1994-2010 metais. Visuomenès sveikata = Public health. Vilnius: Higienos institutas. (Originalūs straipsniai). ISSN 1392-2696. 2011; 3(54): 78-86. Prieiga per internetą $<$ http://www.hi.lt/content/vs2011-3.html>.

3. Zaborskis A., Lagūnaitè R. Vaisiai ir daržovés mokinio valgiaraštyje: mityba ir socialiniai netolygumai 2002-2010 metais. Visuomenès sveikata $=$ Public health. Vilnius: Higienos institutas. (Originalūs straipsniai). ISSN 1392-2696. 2011; 2(53): 65-75. Prieiga per internetą $<$ http://www.hi.lt/content/vs2011-2. html>.
4. Lagūnaite $\mathrm{R}$, Zaborskis A. Ar vaikų mitybos gerinimo programos yra veiksmingos: sisteminé straipsnių apžvalga. Visuomenès sveikata $=$ Public health. Vilnius: Higienos institutas. (Originalūs straipsniai). ISSN 1392-2696. 2011; 4(55): 18-30. Prieiga per internetą $<$ http://www.hi.lt/content/vs2011-4. html>.

5. Zaborskis A, Buivydienè J. Lietuvos gyventojų sveikatos pokyčių prognozė nuo vaikystės išvengus lètinių neinfekcinių ligų rizikos veiksnių: modeliavimo su PREVENT rezultatai. Visuomenès sveikata $=$ Public health. Vilnius: Higienos institutas. (Originalūs straipsniai). ISSN 1392-2696. 2012; 1(56): 22-33. Prieiga per internetą: <http://www.hi.lt/images/ Sveik_1(56)_Zaborskis.pdf $>$.

6. http://www.ve.lt/naujienos/visuomene/psichologija/laimeigimta-uzdirbta-ar-isikalbeta/

\section{EATING HABITS OF DIFFERENT GENDER ADOLESCENTS COMPARISON IN UTENA REGION Ž. Kuprènaitė, J. Lubienè, R. Ubeikienė}

Key words: adolescents, gender, eating habits, a healthy diet, school.

Summary

Recently a prevalence of the eating disorders - anorexia, bulimia and binge eating can be observed. Manifestation of these disorders in adolescence worries a lot. It is important to compare eating habits of the different teen gender, in order to discern possible trends and predict potential problems of preventive measures, because inadequate eating habits, eating disorders in adolescence have more negative effects than for adults. This study was designed to compare eating habits of the different gender teen. The study revealed the eating habits correctness, but it is especially important to proper eating habits with the necessary care individually - in the family with adolescents and at school - student's everyday environment and public levels.

Correspondence to: jolitalub@gmail.com

Gauta 2014-10-30 